\title{
3 \\ Immigration and the limits of statistical government
}

Camden Town Hall in North London is a popular venue for weddings and civil ceremonies. In November 2013 it was the venue for the marriage of a Miao Guo, a Chinese national in her twenties and Massimo Ciabattini, an Italian man in his thirties, for which elaborate preparations had been made, including a post-service reception and a hotel room for the night. The ceremony was dramatically interrupted by Home Office Immigration Enforcement officers wearing flak jackets and accompanied, oddly enough, by journalists.

The couple were pulled apart and taken into separate rooms for questioning. Bridesmaids were also interviewed. This happened because of a tip-off from the registrar, who suspected the marriage was a sham (being undertaken to get a visa), after observing that the couple had had trouble spelling each other's names. Half an hour of questioning later, and with abundant evidence that the marriage was not a sham, the government officials left and the ceremony was restarted (Hutton, 2013; Weaver, 2013). A Home Office spokesman was reported to comment at the time of this failed raid, it is either the best sham wedding I have ever seen or it is real' (Hutton, 2013).

Journalists had been invited to the raid in the hope that they could write about UK immigration control in a more impressive light than the one that transpired. 'Performance politics', as discussed in the previous chapter, requires the state to put on convincing public displays that the 'audience' finds compelling. The performance of the border as a space of fear and potential violence has to infiltrate the public sphere, in this case with the help of the local media.

While the performance politics of raids work to spread fear, this incident also reminds us of the fragility, or even the stupidity, of contemporary immigration policy. Where policy is operating primarily at the level of affect, psychological manipulation and appearances, there is always the potential for this to blow back at those with power. Making things seem 'real' is an ongoing challenge, especially for the 
Home Office because - in a way which no other Whitehall department faces to the same extent - media attention to immigration is relentless and highly charged politically. As we learnt through our interviews, virtually everything the Home Office does must be considered with audience reaction in mind, shaping its policy-making and implementation processes.

Developing the insights into performative politics drawn from Shirin Rai's (2015) work in Chapter 2, here we seek to understand government immigration campaigns in terms of the logics, rationalities and anxieties that underpin them. We will do this by exploring the techniques of government used in Operation Vaken through an engagement with, and extension of, the terms circulating in policy circles themselves, framed through questions of liberalism, neoliberalism, postliberalism and preliberalism. In doing so, we pull out some of the contradictions demonstrated in the previous chapter whereby tools of persuasion and enforcement rely each on the other. The analysis in this chapter is informed by a number of discussions and interviews with policy-makers and advisers, many of which were necessarily off the record. These included current Home Office and former Home Office officials, and also civil servants from elsewhere in Whitehall, including the Department of Business, Innovation and Skills (BIS) and the Treasury.

In summary, in this chapter we discuss government migration campaigns in terms of the policy logic that shapes them. Specifically, we argue:

1 Liberal government treats issues like migration in the aggregate, meaning that statistics and macroeconomics tend to be the ultimate arbiters of 'good' policy.

2 This emphasis on aggregates has lost legitimacy where migration is concerned, meaning that the politics and policy of migration is increasingly dominated by affective, symbolic and mediated issues.

3 In place of liberal government, a distinctive style of policy and politics has emerged in the Home Office, that is an elaborate and occasionally threatening form of reputation management.

\section{Liberalism via quantification}

We have the chance in this century to achieve an open world, an open economy, and an open global society with unprecedented opportunities for people and business.

(Tony Blair, speech to the World Economic Forum 
Migration is likely to enhance economic growth and the welfare of both natives and migrants ... There is little evidence that native workers are harmed by immigration ... The broader fiscal impact of migration is likely to be positive.

(Cabinet Office, 2001: 5-7)

In terms of the politics of migration, the above quotes seem to come from a very different political era to the one in which we write. The proportion of the British public mentioning 'immigration' as one of the most important issues facing Britain was under 10 per cent in 2000, but had risen to over 40 per cent only eight years later (Duffy and Frere-Smith, 2014). The case for greater migration at this time was both normative and utilitarian: people should be allowed to live where they choose, and moreover this will bring benefits in terms of levels of wealth and quality of life overall. Within a decade, this sort of rhetoric had disappeared from mainstream policy discourse. But in order to understand the rationalities (and irrationalities) of contemporary government of migration, we need to consider how the normative and utilitarian argument for freedom of movement has functioned until relatively recently.

In a lecture series given at the Collège de France in 1977-78, the French philosopher Michel Foucault identified two parallel forms of political power that together constitute the modern state (Foucault, 2007). Firstly, there is the 'perspective' that Foucault defines as 'sovereignty', which aims at securing the borders and interior of a given territory. The chief purpose of a sovereign is to keep things as they are, that is, to continue to be respected as the sovereign within borders that do not shift. This conceptualisation was present in the sixteenthcentury English philosopher Thomas Hobbes's classical vision of the modern state. For Hobbes, sovereign power is centralised and sufficiently potent that it can oblige obedience from all of its 'subjects'. As Foucault explains, 'the end of sovereignty is circular; it refers back to the exercise of sovereignty. The good is obedience to the law, so that the good proposed by sovereignty is that people obey it' (Foucault, 2007: 98). Securing borders, enforcing law and defeating enemies are the key tasks of a sovereign.

Secondly, there is the 'perspective' of 'government'. Where sovereignty is focused on applying given laws within a particular territory, government looks at how to facilitate and encourage certain dynamics within a population. This is a very different way of conceiving of politics:

Population no longer appears as a collection of subjects of right, as a collection of subject wills who must obey the sovereign's will 
through the intermediary regulations, laws, edicts and so on. It will be considered as a set of processes to be managed at the level and on the basis of what is natural in these processes.

(Foucault, 2007:70)

The 'processes' in question are effects of individual behaviour and choices, scaled up to the level of the population as a whole. Births, deaths, marriage, sickness, productivity, income, assets and so on are aspects of the population that government is concerned to improve - or at least, not to damage. To this list, we might add migration, as it can affect the size of a population.

Over the eighteenth century, this form of power became predominant in European states, producing a new form of administrative government able to act on population in an expert and measured fashion. To do this, new forms of quantitative knowledge were required, capable of representing population dynamics. In particular, Foucault points to the rise of political economy in the late eighteenth century, focused on markets but also on other 'natural' dynamics influencing population such as agricultural production and birth rates. No less importantly, statistics offered a basis on which to represent things in the aggregate, so that trends and empirical laws could emerge amongst events that otherwise would seem contingent, accidental or moral and political in nature. In this way, the statistical gaze takes normative questions of individual conduct or indeed chance, and scales them up until they are empirical questions of population dynamics.

This statistical view of society is simultaneously liberal and scientific: its liberalism is entrenched in its methodology. There are various ways in which we can understand this synthesis of quantitative social science and liberalism. Firstly, modern statistics assumes that aggregate processes are the result of diverse individual decisions, preferences and judgements. As Foucault puts it, the one thing that government assumes is common to all people is 'desire'. Thus, the driving force behind migration flows, for instance, is assumed to be freely taken choices to seek work, better quality of life, family reunification, education or whatever else. The governmental perspective on a problem such as migration would involve seeking to alter the value of these different goals, so as to influence the aggregate dynamics in certain ways.

Secondly, statistics have a liberal quality because they aim to take everyone into account. In the search for the normal or average individual, statisticians were also seeking a way of representing society as $a$ whole. The governmental emphasis on the aggregate is a tacit form of collectivism that potentially allows individual conduct to be judged 
in terms of how it effects net outcomes, rather than on the basis of any political, moral or cultural value or prejudice.

Thirdly, statistics potentially have a cultural blindness about them, at least on some questions. All quantitative methodologies involve some assumption of equivalence (Desrosières, 1998), through which multiple and separate cases can be treated in the same way. Where differences are being represented, they are represented on the basis of some principle of potential sameness. So, in order to say that 'he is 20 per cent taller than her', there must be a shared idea called 'height' and a shared understanding of proportions.

What has become known as 'evidence-based policy-making' or doing 'What Works' is an effort to promote a dispassionate, scientific perspective within government. The utilitarian statistical ethos can serve as a way of keeping unwelcome cultural and political questions at bay, bracketing issues of 'policy' as if separate from those of 'politics'. France, for example, famously leaves out questions of ethnicity from its national statistics data, ostensibly on the basis that ethnicity does not affect the status of French nationals as citizens. But this omission makes it harder to speak authoritatively about the extent of racism in French society. In a more technocratic spirit, emphasising economic growth as the ultimate indicator of progress allows an issue like migration to be culturally and politically diffused (as New Labour sought to do), and each new arrival into the country can be viewed simply as another anonymous contributor to aggregate output. Economics is potentially the most effective tool for depoliticisation of an issue. For instance, representing an issue as a matter of expertise, economic evidence and policy is a way of keeping it separate from matters of identity, ethnicity and politics. Viewing it from the perspective of government can be a way of avoiding the perspective of sovereignty. For various reasons, this strategy no longer seems to work in the British context. Before we explore this failure further, we need to consider two alternative rationalities of power that represent a departure from statistical liberalism.

\section{Rationalities of disaggregation}

As the sociologist and statistician Alain Desrosières (1998) has highlighted, the statistical focus on population aggregates depends for its legitimacy on some universalist, quasi-democratic idea of 'society', in which we all have a stake. Yet it is precisely a sense of the social aggregate that has been gradually dismantled as an object of government since the 1970s (Rose, 1996b). While it was possible for New Labour 
to use GDP as a justification for migration in the early 2000s, it is telling that public anxiety about migration rose long before the recession, which began in early 2008. Aggregate welfare does not count for much when individuals are concerned about their own personal welfare, and view immigration as a direct threat to it.

What happens if statistical government is no longer adequate for purposes of administrative decision-making? Two alternative forms of rationality are worth noting: neoliberalism, and 'postliberalism' as it has been discussed in the recent British policy context. While these are mutually antagonistic in various ways, they share a tendency to disaggregate, dissociate and distinguish worthy populations from unworthy populations (see also Chapter 5). Rhetorically they are poles apart, but they have a mutual compatibility that is often overlooked, as we now explore, starting with neoliberalism.

\section{Neoliberalism}

In Foucault's account, the key difference between liberalism and neoliberalism lies in how the market is represented and idealised. Liberalism views the market as a separate space of autonomous freedom, outside of the social and political spheres; neoliberalism treats all spheres of human conduct and all human capacities as essentially economic in nature (Brown, 2015). From a neoliberal perspective, economic choices are not simply those which are exercised in the marketplace in the process of monetised exchange but all choices regarding how to use one's free time, who to marry, who to vote for, what to learn, and how to live. The key function of competition, from a neoliberal perspective, is that it distinguishes that which is most valuable, whether inside or outside the market. Hence, the main virtue of capitalism is its capacity to separate people out (winners from losers, leaders from followers, strivers from skivers), rather than to integrate in the way that economic liberals had celebrated since Adam Smith. For this reason, nationalism can play an important part within neoliberalism, to the extent that nations are acting like competitive units, striving to become the 'best' and to 'beat' others in the 'global race' (Davies, 2014). As the geographer David Harvey puts it, 'the neoliberal state needs nationalism of a certain sort to survive' (2005: 85).

One of the most celebrated exponents of the neoliberal worldview was the Chicago School economist Gary Becker, whose concept of 'human capital' assumed that individuals had the freedom to augment themselves, through education and other decisions, so as to increase their economic value in the marketplace (Becker, 1976). Viewing 
humans as items of 'capital' rather than as members of population has a disaggregating effect, which represents a departure from liberal governmentality. In the sphere of migration, it is manifest in the much-heralded 'Australian-style points system', which assesses applications for residency by adding up points earned on the basis of age, skills, qualifications and linguistic ability.

This points-based system has been much celebrated by right-wing politicians in the UK, and was adopted as the official policy of the UK Independence Party (UKIP) in the run-up to the 2015 election and the $2016 \mathrm{EU}$ referendum - ignoring the fact that such a system had already been introduced by the Labour government for non-EU nationals, in effect from 2008. The curious forms of political triangulation that the 'Australian-style points system' has enabled can be seen in the then UKIP leader Nigel Farage's claim that this system is the only 'fair' one (Farage, 2015) and UKIP's defence of its 'principle of equal application to all people' (UKIP, 2015, n.p.).

The idea of a 'points-based system', rooted in calculations of human capital, has the veneer of administrative governmentality, but it conceals a more violent sovereign logic focused on inclusion and exclusion. It may even serve to entrench certain prejudices, regarding the work-rate or economic mindset of different cultural identities. Increasingly, immigration is a policy area where governmentality and sovereignty are entangled in ways that collapse arguments about economics and national identity into one another. It is worth recognising the extent to which neoliberal rationality - which extends economics into all spheres of conduct - facilitates this entanglement.

\section{Postliberalism}

The idea of 'postliberalism' emerged in UK policy discussions in the years immediately following the global financial crisis, along with the terms 'Red Tory' and 'Blue Labour'. ${ }^{1}$ As the names indicate, this

\footnotetext{
${ }^{1}$ In the UK, red is associated with left-wing politics and the Labour Party (through residues of socialism) and blue with the right-wing Conservative (or 'Tory') Party (the opposite of these colours' political associations in the USA). 'Red Tory' refers to Conservatives with political sympathies with certain 'left-wing' values, such as social security, community and equality. 'Blue Labour' refers to Labour supporters with political sympathies with certain 'right-wing' values, such as tradition, nationalism, family and cultural homogeneity. These agendas are heavily overlapping and their protagonists are in regular dialogue with each other.
} 
mixing up of categories was a way of transcending left/right political divisions, laying out a more socially conservative and economically localist new policy agenda (Blond, 2010; Geary and Pabst, 2015). Fuelling this new intellectual insurgency was a sense that policy orthodoxy had been set by a technocratic metropolitan elite, whose support for migration was out of step with the rest of the country (see also Chapter 6). In the words of Blue Labour 'guru' Maurice Glasman, 'on managerialism, modernity and the market, Blair ultimately served the interests of the rich and the status quo' (Riddell, 2011, n.p.). Often, the blame was deemed to lie specifically with economists:

Freedom of movement at moderate levels, like immigration itself, is a benefit both to the movers and the country they move to. But the liberal economists and politicians who dominate the EU debate gave little thought to large-scale movement nor do they seem to have realised the extent to which they were eroding national social contracts.

(Goodhart, 2014)

For the political commentator David Goodhart, who has done the most to advance the idea of 'postliberalism', opposition to immigration is an inevitable outcome of natural psychological tendencies that lead us to favour 'people like us' (Goodhart, 2014). Liberalism, for Goodhart, is ultimately a denial of human nature, just as economics is when it views people as isolated rational utility-maximisers. In its avowed localism and populism, postliberalism explicitly rejects the centralised, technocratic perspective of the statistician and the economic administrator. Part of the postliberal critique is that liberal government acts in an impersonal, generalising, calculated manner, preventing a more ethically substantive or publicly meaningful form of policy. Yet what such an alternative policy would be is by definition impossible to formalise as a set of rules. Glasman, for example, suggests that a much tighter immigration policy would still need to make 'exceptions' on ethical grounds, but the postliberal ethos resists systematising these (Riddell, 2011).

Despite this inconsistency, we can make out a certain resonance between the postliberal critique of economics and the psychological critique of economics, which has produced behavioural and happiness economics. Goodhart claims that postliberalism 'has a view of human nature that aims to capture people in their messy reality rather than reduce them to a single, dominant drive such as self-interest or a desire for autonomy' (2014: 1). Yet he also claims that group attachments are 'hard-wired into us' and that a preference for 'people like 
us' is a 'simple reality of life', suggesting that for him there are nevertheless a few dominant psychological (or biological) drives that can be isolated when developing policy. This is an example of what might be termed 'neocommunitarianism', in which psychological and biological evidence is used to help reconstruct the government of individual decision-making (Davies, 2012). The rise of 'nudging' as a way of altering individual behaviour through the redesign of 'choice architectures' is another example of this, through which everyday techniques such as 'social marketing' and food-labelling can be seen as forms of intervention (Jones et al., 2013).

A key feature of behaviourally attuned policy is that it pays far greater attention to the aesthetics and affective dimensions of governmental intervention, so that all sorts of other factors come into play, including the learnt habits, emotions, neurological substrates and social influences that condition behaviour (Dolan et al., 2010). Altering behaviour is a matter no longer simply of tweaking 'incentives' but of altering multiple aspects of the social and material environment, in much the way that advertisers have long done. As we shall explore, this heightened policy attention to emotions and behaviour related to migration is arguably a key feature of the postliberal government and 'performance politics', although the notion that experts might seek to influence individual behaviour through manipulating their environment is far from new.

Attempts to anchor advertising and management in scientific psychology date back to the 1920s (Baritz, 1960; Rose, 1996a). Governments have attempted to influence psychological indicators such as 'public opinion' and 'morale' for almost as long. But the rise of 'nudging' in the early twenty-first century represents a renewed concern with small-scale cultural and visual messaging, which bypasses the conscious mind or explicit discussion. In that sense, it shares a communicative rationality with 'dog whistle' politics, recognising that the implicit and oblique dimensions of public discourse can be more powerful than what is explicit or direct. While nudging remains a technocratic pursuit, its concern with the performative, normative and symbolic dimensions of policy interventions is in keeping with postliberal critique.

In its antipathy to elites, technocrats and orthodox economics, postliberalism is ultimately a challenge to the very idea of 'government', in Foucault's sense of an 'administration of things ... a technology of power' (Foucault, 2007: 49). It is certainly an affront to statistical government, which employs models and aggregates as the measure of all political action. It resists the very idea of treating all people in the same way, which it characterises as a metropolitan 
conceit. Yet in doing so, it inadvertently corroborates aspects of the neoliberal project of rationalised discrimination, which seeks to separate the enterprising from the non-enterprising. Both rest on a critique of the generalising aspect of liberalism, and an effort to develop policies capable of distinguishing the worthy from the unworthy migrant (see Chapter 5). Both depart from the abstractions of the free market, towards an account of underlying human drives - competitiveness for neoliberals, and cultural sameness for postliberals.

Most significantly, both neoliberalism and postliberalism signal a revival of sovereign power and a commensurate decline in liberal governmentality in Foucault's sense. Political questions of territory, nationhood, border, security and law return to the fore, overwhelming (or perhaps co-opting) questions of efficiency, macroeconomic growth, utility and aggregate welfare in the process. The need to display 'toughness' on immigration, to speak in terms of national symbolism (as opposed to aggregate outcomes), to sympathise with personal and local experiences of migration (as opposed to evidence of macroeconomic effects) has led to a collapse in the imagined distinction between 'policy' and 'politics', to the point where Home Office policy-makers mobilise images of state violence and far-right rhetoric in order to manage migration. We now consider how this intermingling of 'policy' and 'politics' appears from the perspective of the Home Office itself.

\section{Rationalities of contemporary migration policy in the UK}

Being able to interview civil servants is always difficult. It involves a high degree of trust, and even then gaining consent to record an interview is almost impossible. Having an informal coffee with a government official, accompanied by a notebook, is the more likely scenario. However, with migration policy, even this turns out to be a something of a stretch, such are the sensitivities, controversies and media interest in this area. The potential costs of any discussion of the topic are deemed too high to take risks.

Through a series of introductions, however, Will was able to meet with civil servants, including past and present Home Office officials, although on very strict terms. Attempts to 'snowball' these contacts (i.e. to use them to establish contacts for further interviews) had mixed results. When a mere reference was made about wanting to meet another Home Office official, for example, a terse email quickly arrived from Will's first contact, pointing out that this was a clear 
breach of the agreed secrecy surrounding their discussion. Employees of think tanks are understandably less paranoid, and interviews with influential immigration policy thinkers were more straightforward.

What follows, then, is a collection of impressions and reports from a series of conversations - in various coffee shops around Westminster - over the course of 2013-14. While these didn't generate 'data' in any tangible, duplicable form, they played an important part in our project, helping us to glimpse something of the problem of immigration as it appears to those in Whitehall, and the Home Office in particular. Especially for the latter, we got a strong sense of an organisation that feels embattled and misunderstood, both by the rest of Whitehall and by liberal critics. This no doubt contributed to the lack of enthusiasm for co-operating with a sociological research project.

The governing rationality of the Home Office seems to be very different from that of other Whitehall departments, and we were interested in understanding how and why this is, with a view to better understanding how a policy such as Operation Vaken becomes possible. In the terms outlined in this chapter, it would appear that various aspects of contemporary migration policy defy basic tenets of liberal government. The question is whether they might be any better understood in terms of neoliberalism or postliberalism.

One significant feature of migration as a contemporary policy issue is that efforts to treat it as 'just' a matter of policy often produce the opposite of the desired effect. Liberal techniques of depoliticisation outlined in this chapter tend to be not simply ineffective but counterproductive. Research carried out by the think tank British Future on attitudes to migration found that, when politicians or businesses discuss the economic benefits of migration to the national economy, this can produce some very negative reactions (Katwala et al., 2014). Talk of benefits to the 'national economy' in focus groups led to the response that this wasn't a benefit to my economy. As one of the policy-makers we interviewed remarked, 'while the Treasury might be believed on its growth figures, it will never be believed on its economic impacts of immigration'. A study conducted on belief in conspiracy theories across the UK population found that 55 per cent of people believe the statement 'UK Government is hiding the truth about the number of immigrants living here' is probably or definitely true, compared to only 25 per cent believing it is definitely or probably untrue (Faulkner Rogers, 2015).

Research on attitudes repeatedly finds a common view, that people believe that politicians and policy-makers do not know or care how migration is affecting local streets or local labour markets. British Future classed the majority of the British public as the 'anxious 
middle', to whom talk of the macroeconomic benefits seems untrustworthy or patronising. Efforts to ground a public debate about migration in a set of 'facts' or statistics are found to harden the position of those who are sceptical about immigration, to whom statistics are associated with the interests of politicians and elites. As British Future argues, "People understand "the economy" through their direct experience - jobs, wages and the money in their pocket - rather than through GDP and macroeconomic statistics' (Katwala et al., 2014: 28).

Instead of focusing on statistics and economics, there is a perception that politicians and businesses need to speak a more emotional and communitarian language, focused on qualitative human experiences and anxieties. For many of the policy-makers we spoke with, this meant sympathising with the view that it's 'not racist' to want less immigration; recognising deep-set anxieties about the competence of the state to secure the border; understanding that immigration can cause disorientating social change at a local level, including in the labour market. To do this, political rhetoric has to switch away from utilitarian liberalism (of economics and statistics) towards the language of belonging, national identity, security and symbolism. Or in Foucault's terms, migration policy needs to be viewed from the perspective of sovereignty not of governmentality. One interviewee gave an example of a meeting chaired by the then Prime Minister David Cameron, in which someone referred to migration 'regulations', to which Cameron responded tersely - 'those aren't regulations: they're the law'. The message here is that migration cannot be treated as a purely administrative issue without inciting impassioned public responses. One way of pursuing this is to simply refuse engagement in statistical-utilitarian discussion. A written question by Labour peer Lord Beecham asked the Treasury to reveal 'the annual benefits paid to EU migrants in the UK and the contribution of those individuals to the public purse through income tax receipts and VAT', to which the answer came back in February 2016 'the information is not available' (Waugh, 2016). On the other hand, it is argued that once the qualitative, emotional and local perspective of voters has been expressed, the legitimacy of more open borders and labour markets might be restored to some extent. This was the view expressed to us by many of the policy-makers we spoke to, including in the Home Office. Subsequent political developments, particularly debates and developments around the UK's June 2016 referendum on whether to remain a member of the $\mathrm{EU}$, do not appear to have borne out this latter argument. 
The qualitative, affective impact that the state seeks above all others is an image of being 'tough' at the border. We were told that private polling had been carried out by the Home Office under the Labour Home Secretary John Reid in the mid-2000s, which found that the public was more trusting of uniformed border agency staff (who are perceived as characteristically 'tough') than of politicians (who are perceived as characteristically liberal and metropolitan). Following this, a rebranding of the UK borders was undertaken in 2006, so as to amplify the sense of a national border, via flags, insignia, uniforms and other symbols (see also Chapters 1 and 2). Meanwhile, a communications strategy aimed at getting more images of immigration raids into the media was launched as early as 2006, long before the Home Office's social-media-based campaigns of 2013. This included inviting journalists along to witness raids, so as to divert media attention to the physical 'toughness' of the border, and away from the rhetoric and perceived elitism of politicians. Ultimately, the very fact that vans displaying the message 'Go Home' were ever driven around Britain's streets at all needs to be understood in the context of this perceived need for the state to seem tough in the eyes of the voting public. Of course, this ignores the fear that such messages inculcate amongst various marginalised populations, as we will discuss in subsequent chapters.

A second significant feature of migration as a policy issue is that it has a very high media profile, meaning that the Home Office often tends to develop new policy and respond to policy failures at an unusually high speed. While some interviewees suggested that keeping migration out of the news altogether was the ideal political scenario for the Home Secretary, the medium-term implausibility of this means that any Home Office needs to pay constant attention to the news cycle. We were unable to discover precisely how the Go Home vans and accompanying Twitter campaign had been conceived, but most interviewees took the view that it had likely been an ill-thought-out effort within the Home Office communications team to win positive headlines amongst the anti-migration media. Interviewees suggested that being perceived as illiberal in the media (or upsetting the liberal media) is something the Home Office communications team is generally pleased with. On the other hand, given deep levels of mistrust in the government's ability to manage immigration, even very tough messaging can backfire if it reminds the public of issues (such as illegal immigration) that have otherwise fallen out of the news cycle.

Coupled with the challenges that come with immigration having such a high media profile is a recognition that, since the early years 
of the twenty-first century, migration has become one of the top two issues (and often the top one) that concern the voting public, according to polls (Duffy and Frere-Smith, 2014). Some of those interviewed by Will argued that this places the Home Office in a very different position from other, more technocratic, less popularly controversial Whitehall departments. This context means that policy 'success' and 'failure' are something other than mere technical efficacy or efficiency. Policies need to look effective, as much as be effective, something which other Whitehall departments do not necessarily understand. As one policy-maker put it:

its sheer salience is also important ... an approach which says 'let's insulate rational policy from public politics' just isn't viable with this level of salience.

(Policy interview, conducted by Will)

Others suggested to us that the awareness of depth of public feeling on the topic pervaded the Home Office, influencing migration policy development at every step. This emerged also in our negotiations with the survey company on the wording of some of the questions in the survey we commissioned, where there was nervousness about asking questions which might produce critical findings about the Home Office as one of its major clients (see Living Research Six).

The Home Office's own stated rationality for the Go Home vans was an economic one, as set out in their published evaluation (Home Office, 2013). Voluntary repatriations of 'illegal immigrants' cost the government on average $£ 1,000$ per person, while enforced ones cost $£ 15,000$, so encouraging those 'in the UK illegally' to 'go home' has apparent fiscal justification. The Home Office official we spoke to explained that the policy of helping 'illegal immigrants' to leave the country is actually a 'generous' one, in that their airfare is paid for by the taxpayer. While the vans alluded to 'free advice and help with travel documents', they made no mention of the free airfare, which our Home Office interviewee explained was necessary to avoid antagonising the tabloid press. From the Home Office's perspective, the position of the media makes this an impossible situation, in that the British state is unable to publicise the full 'help' it is actually providing people to 'go home', for fear that this would seem like a free handout to the undeserving. In other words, the messaging of 'Go Home or face arrest' came out of an effort to increase voluntary repatriation, while continuing to appear 'tough' on illegal immigration. There is little consideration here for whether this, or the posters stating 'Is life here hard? Going home is simple', 'This plane can take 
you home, we can book your tickets' displayed in immigration reporting centres to asylum applicants might be viewed as threatening, rather than generous, by those seeking refuge from dangerous 'home' countries. As one of the speakers at a research event we held in Glasgow, a member of the 'Glasgow Girls' (see Chapter 4) who had gone through the asylum system herself and continued to campaign on migrants' rights issues, said:

I mean, having little planes hanging from the ceiling, you know, these are people who are seeking sanctuary and you're basically telling them, 'Life in the UK's difficult, going home is simple.' It's not simple. You know, I would love to see them trying, go to some of these countries and see how long they would last in it.

(Amal Azzudin, speaking at MIC policy briefing in Glasgow, April 2014)

The emotional responses of those who were ostensibly targeted by the posters offering voluntary removal appeared less important to the Home Office than the economic efficiency of the campaign, however. The formal evaluation of the Go Home vans suggested that they represented a cost saving to the taxpayer. The campaign cost only $£ 9,740$, but was deemed responsible for sixty voluntary repatriations. According to the Operation Vaken evaluation, removal of these sixty people could otherwise have cost up to $£ 830,000$ in enforced departures or up to $£ 260,000$ a year in costs to public services (Home Office, 2013). A different question is whether they were also deemed a public communications success. It seemed as if the level of publicity that the vans attracted was never predicted, and there was anger expressed in various media outlets and by senior politicians.

The fact that the campaign was not repeated, despite the alleged fiscal benefit, would suggest that it was not judged as a political success overall (see Chapter 1 for discussion of the challenges to the campaign by RAMFEL and those who complained to the Advertising Standards Authority). However, the publicity - which coincided with the Twitter campaign of raids being photographed - may be assumed to have had some 'dog whistle' benefits, from the perspective of communication strategists seeking to appease the anti-immigration sections of the public. The extent of this 'secondary' messaging - and ways it may have backfired, such as increasing anxiety that immigration is a severe enough problem to require such tough measures - was explored in our research and these findings are discussed in subsequent chapters. 
The exceptional status of immigration, as an issue that defies reduction to the status of an economic or statistical matter, needs to be seen in the context of the Home Office's own exceptional status. The ministry has been frequently mired in controversies and media attacks, leading it to be represented as a 'political graveyard' (Painter, 2008). The Home Office is responsible for areas of policy that are especially enticing from the perspective of the tabloid press: policing, prisons, terrorism, asylum, drugs, antisocial behaviour, all in addition to migration. This means that the department as a whole operates on a relentless communications cycle, which inculcates a sense of paranoia and watching one's back. In addition to this, there are deep structural reasons why the Home Office encounters regular conflicts with other Whitehall departments, especially where the latter operate according to more liberal economic rationalities. For these reasons, one interviewee joked that the internal philosophy of the Home Office could be summed up by the well-known chant of Millwall football fans, 'No one likes us, we don't care'.

\section{Neoliberalism with a postliberal face}

The celebratory rhetoric of 'globalisation' that characterised the early New Labour years may have been largely a reiteration of government commitments to 'business' and market 'flexibility', but it had one political advantage as well. It offered a language with which elites could speak publicly about the political economy that they subscribed to, namely one based around market liberalism. From this perspective, as we have discussed, migration represents a net benefit in the aggregate, because it increases labour market efficiency and represents a positive contribution to the macroeconomy. Lurking within this ideology is the potential for a more discriminatory neoliberal perspective, which distinguishes between different migrants in terms of their human capital or capacity for innovation or likely balance of fiscal costs and benefits. However, we can at least say that the turn of the millennium represented a time when the openness of national economies to international markets (including labour markets) was something that was spoken of by politicians.

The context which gave rise to Operation Vaken and related initiatives was one in which this type of empirical discourse is no longer deemed acceptable, at least where the movement of human beings is concerned. The then Chancellor of the Exchequer, George Osborne, was able to say in early 2016 that the UK economy was vulnerable to a 'cocktail of threats' posed by global economic uncertainties, as if 
this might strengthen him politically. However, the nature of migration policy and the political position of the Home Office means that the Home Secretary cannot discuss the movement of people in economic or statistical terms, let alone refer to it as something beyond state control. Least of all does it appear as something that can be celebrated. This represents a grave problem for democracy and the public sphere, as migration levels tend to rise and fall in tandem with macroeconomic growth, and the inability to discuss this from what Foucault called the 'perspective of liberal government' means that political rhetoric and policy ends up focused instead on seeking to shape attitudes and emotions of (sections of) the public. Attempts to speak scientifically or realistically about this policy issue are no longer viewed as legitimate by large swathes of the British political class.

Postliberalism does not offer a new paradigm of governmentality, as its purpose is to attack the very idea of centralised, technocratic, statistically informed government. It does however suggest that policy-makers should become more attuned to the affective, emotional and symbolic dimensions of the state, and become more expert in manipulating how these are seen and felt. Arguably, Operation Vaken was a case of such postliberalism, in which the violent qualities of the sovereign state were displayed in billboard form, in order to impress an alternative sense of toughness, reassurance and fear across particular communities. This postliberalism has certain formal qualities in common with preliberalism, or violent public demonstrations of power as described by Foucault at the opening of Discipline and Punish (1991), to the extent that it involves heightened attention to ritual, symbolism and the aesthetics of political action. And yet it also bears the hallmarks of postliberal 'nudging' and 'dog-whistling', in which a message is carefully crafted to communicate in an unconscious or coded fashion with particular groups. Marketing and sovereignty therefore reach new alliances, squeezing out the space of liberalism: the marketing campaign aimed at representing Britain as a 'hostile environment' or the rebranding of the UK borders to look 'tougher' would be examples of such new alliances between the traditional goals of sovereignty and the latest techniques of affective management.

Leaving aside ethical questions, what is epistemologically and technically problematic about this postliberal or neo-communitarian emphasis upon emotional attachments and prejudices is that it is constantly at risk of being found out, given the underlying governmental, statistical and economic reality from which it seeks to distract. The wishful thinking of postliberalism is that nostalgically imagined nationhood, cultural homogeneity and locality can be restored, despite 
neoliberal trends pulling in the opposite direction. It represents a failure of political discourse to adequately represent the sociological, historical, political and economic forces that produce high levels of migration in the first place, and opts for soothing communitarianism instead. Postliberal rhetoric tends to conceal neoliberal reality but not thwart it. What concerns us is that, in doing so, it further isolates and attacks those citizens and non-citizens who are seen as lacking value in both neoliberal and postliberal terms.

\section{References}

Baritz, L. (1960) The Servants of Power, Middletown, CT: Wesleyan University Press.

Becker, G.S. (1976) The Economic Approach to Human Behavior, Chicago: University of Chicago Press.

Blair, T. (2000) Speech at the World Economic Forum at Davos, Switzerland, 18 January, http://webarchive.nationalarchives.gov.uk/ 20060715135117/number10.gov.uk/page1508 [last accessed 22 May 2016].

Blond, P. (2010) Red Tory: How Left and Right Have Broken Britain and How We Can Fix It (Main edition), London: Faber \& Faber.

Brown, W. (2015) Undoing the Demos: Neoliberalism's Stealth Revolution, Cambridge, MA: MIT Press.

Cabinet Office (2001) Migration: An Economic and Social Analysis, London: Her Majesty's Stationery Office.

Davies, W. (2012) 'The emerging neocommunitarianism', The Political Quarterly, 83 (4): 767-76.

Davies, W. (2014) The Limits of Neoliberalism: Authority, Sovereignty and the Logic of Competition, London: Sage.

Desrosières, A. (1998) The Politics of Large Numbers: A History of Statistical Reasoning, Cambridge, MA: Harvard University Press.

Dolan, P., Hallsworth, M., Halpern, D., King, D. and Vlaev, I. (2010) MINDSPACE: Influencing Behaviour through Public Policy, London: Institute for Government.

Duffy, B. and Frere-Smith, T. (2014) Perceptions \& Reality: Public Attitudes to Migration, London: Ipsos MORI.

Farage, N. (2015) 'UKIP's immigration policy is built on fairness', The Daily Telegraph, 3 March, www.telegraph.co.uk/news/politics/nigelfarage/11447132/Nigel-Farage-Ukips-immigration-policy-is-builton-fairness.html [last accessed 22 May 2016].

Faulkner Rogers, J. (2015) 'Are conspiracy theories for (political) losers?', YouGov, https://yougov.co.uk/news/2015/02/13/are-conspiracytheories-political-losers/ [last accessed 15 May 2015]. 
Foucault, M. (1991) Discipline and Punish:The Birth of the Prison, London: Penguin.

Foucault, M. (2007) Security, Territory, Population: Lectures at the Collège De France, 1977-78, Basingstoke: Palgrave Macmillan.

Geary, I. and Pabst, A. (2015) Blue Labour: Forging a New Politics, London: I.B. Tauris.

Goodhart, D. (2014) The British Dream: Successes and Failures of Post-War Immigration, London: Atlantic Books.

Harvey, D. (2005) A Brief History of Neoliberalism, Oxford: Oxford University Press.

Home Office (2013) Operation Vaken Evaluation Report - October 2013, London: Home Office.

Hutton, A. (2013) 'Exclusive: "sham marriage" police storm real wedding', Camden New Fournal, 7 November, www.camdennewjournal.com/ news/2013/nov/exclusive-sham-marriage-police-storm-realwedding [last accessed 22 May 2016].

Jones, R., Pykett, J. and Whitehead, M. (2013) Changing Behaviours: On the Rise of the Psychological State, Cheltenham: Edward Elgar Publishing.

Katwala, S., Ballinger, S. and Rhodes, M. (2014) How to Talk about Immigration, London: British Future.

Painter, C. (2008) 'A government department in meltdown: Crisis at the Home Office', Public Money and Management, 28 (5): 275-82.

Rai, S. (2015) 'Political performance: A framework for analysing democratic politics', Political Studies, 63 (5): 1179-97.

Riddell, M. (2011) 'Labour's anti-immigration guru', The Daily Telegraph, 18 July, www.telegraph.co.uk/news/uknews/immigration/8644334/ Labours-anti-immigration-guru.html [last accessed 22 May 2016].

Rose, N. (1996a) Inventing Our Selves: Psychology, Power, and Personhood, Cambridge: Cambridge University Press.

Rose, N. (1996b) 'The death of the social? Re-figuring the territory of government', Economy and Society, 25 (3): 327-56.

UKIP (2015) 'UKIP launches immigration policy', UKIP website, www.ukip.org/ukip_launches_immigration_policy [last accessed 8 July 2016].

Waugh, P. (2016) 'How much do EU migrants cost - or benefit - the UK? "Information not available", minister says', Huffington Post, 19 February, www.huffingtonpost.co.uk/2016/02/19/how-much-doeu-migrants-c_n_9272428.html [last accessed 22 May 2016].

Weaver, M. (2013) 'Bungling immigration officials crash genuine wedding', The Guardian, 8 November, www.theguardian.com/ uk-news/2013/nov/08/bungling-immigration-sham-weddinglondon [last accessed 22 May 2016]. 